\title{
Gurinder Chadha's Bride and Prejudice: A Transnational Journey Through Time and Space ${ }^{1}$
}

\author{
ElenA OliETE AldEA* \\ University of Zaragoza
}

Received: 6 July 2011 / Accepted: 24 December 2011

\begin{abstract}
At the beginning of the $21^{\text {st }}$ century, the processes of globalization have propelled intense cultural contacts between formerly cohesive communities resulting in both homogenizing and hybridizing socio-cultural changes (Robertson, 1995: 27); these changes, however, go hand in hand with a "global fear" of a potentially threatening "other", which fuel people to take defensive actions that re-create "protective" prejudices and boundaries (Bauman, 2006: 97). As culturally hybrid products, transnational films not only transcend the limits of cinematic genres but cultural boundaries based on prejudice and uneven power relations. Chadha's transnational movie Bride and Prejudice (2004) includes elements of Hollywood, Bollywood and British cinematic traditions to create a hybrid transnational film that metaphorically represents the re-emergence of past prejudices in contemporary encounters of Eastern and Western cultures. Following a cultural studies methodological approach, this article intends to analyze the competing meanings and interpretations the film offers when set against its globalized cultural background.
\end{abstract}

KEYWORDS: transnational cinema, film genres, diaspora, globalization, hybridity.

\section{RESUMEN}

En los albores del siglo XXI, los procesos de la globalización han intensificado intercambios culturales entre comunidades hasta entonces cerradas, dando lugar a cambios sociales conducentes a la homogeneidad o a la hibridación de las culturas (Robertson, 1995: 27); esta situación también suele ir acompañada del "miedo global" a un "otro" potencialmente amenazador, lo cual provoca acciones defensivas que recrean prejuicios y fronteras "protectoras" (Bauman, 2006: 97). Como producto cultural híbrido, el cine transnacional no sólo transciende los límites de los géneros cinematográficos si no que también traspasa los de las identidades culturales basadas en prejuicios y relaciones de poder desiguales. La película de Gurinder Chadha Bodas y Prejuicios (2004) incluye ingredientes de tradiciones cinematográficas de Hollywood, Bollywood, y del Reino Unido para crear un film transnacional sobre los prejuicios que todavía prevalecen en los encuentros entre Oriente y Occidente. Siguiendo un enfoque metodológico cultural de carácter interdisciplinar, en este artículo se pretende analizar los diversos significados que esta película ofrece cuando se estudia dentro del marco de la globalización cultural.

PALABRAS CLAVE: cine transnacional, géneros cinematográficos, diáspora, globalización, hibridación.

*Address for correspondence: Elena Oliete Aldea. Dpto. Filología Inglesa y Alemana. Facultad de CC. Económicas y Empresariales. Universidad de Zaragoza. Gran Vía 2. 50005 Zaragoza. Email: eoliete@ unizar.es 
In the context of 21st century globalization, cinema plays an important role in both reflecting and contributing to the socio-economic and cultural interactions at stake in "the process of the compression of the world and the intensification of the consciousness of the world as a whole" (Robertson, 1994: 8). As Andrew Higson states, "the media are vital to the argument that modern nations are imagined communities. But contemporary media activity is also clearly one of the main ways in which transnational cultural connections are established" (2006: 17). In this respect, the analysis of filmic productions that deal with transnational issues in terms of production, setting and thematic content become extremely relevant from a cultural perspective. The processes of globalization have propelled faster and more intense cultural contacts between formerly cohesive and separated communities (Steger, 2003: 6). This intense contact, which results in both homogenizing and hybridizing socio-cultural changes (Robertson, 1995: 27), is also accompanied by what Zygmunt Bauman denominates "global fear": "In the liquid modern world, the dangers and fears are also liquid-like" (2006: 97). In other words, fears of a potentially threatening "other" fuel people in globalized societies to take defensive actions and thus re-create prejudices and boundaries that protect themselves from these "other" individuals or communities. Similarly, other critics have signaled the appearance of cultural prejudices in moments of global interaction, that is, when people are confronted with something new and unknown (Hall, 1997: 5-7; Sen, 2007: xii; Weedon, 2004: 20-1).

As culturally hybrid products, transnational films may not only transcend the limits of cinematic genres but also other types of identity boundaries, which are set by cultural confrontations and based on prejudice and uneven social power relations. Against this background, Gurinder Chadha's Bride and Prejudice could be defined as a transnational film due to its mode of production ${ }^{2}$, use of generic conventions, multiple locations and themes raised. Gurinder Chadha includes elements of Hollywood, Bollywood and British cinematic traditions to create a hybrid transnational film. Bride and Prejudice (2004) thus transforms Jane Austen's Pride and Prejudice into an interracial romance that metaphorically represents the re-emergence of past prejudices in contemporary encounters of Eastern and Western cultures. Significantly enough, the movie's particular use of various film genres and diverse cultural traditions has forged opposite reviews by film critics. On the one hand, some reviewers criticize the translation of a classical novel into a musical and accuse Chadha of using the worst part of different genres. Furthermore, based on the division between high and low culture, these critics conclude that Bollywood conventions only work in Indian mainstream cinema and therefore cannot fit in Western realist moviemaking traditions ${ }^{3}$. On the other hand, those critics who take a cultural approach favor Chadha's proposal as a film that cannot be categorized in either Hollywood or Bollywood because of its hybridity and thus it best reflects the South Asian perspective in the times of globalization (http://www.planetbollywood.com/displayReview.php?id=032906 112631; 22/04/2011) . 
Following a cultural studies methodological approach, this article intends to analyze Chadha's cinematic production within the context of South Asian transnational cinema and thus unveil the competing meanings and interpretations the film offers when set against its globalized cultural background.

\section{TRANSNATIONAL IDENTITIES AND SOUTH ASIAN DIASPORIC CINEMA}

Released in 2004, this contemporary adaptation of Jane Austen's classic, which portrays an Indian heroine, Lalita (Aishwarya Rai), and a U.S. American "Mr. Darcy" (Martin Henderson), has appeared at a time when multicultural societies are both promoted and threatened by conflicting discourses on identity and culture. The long-standing struggle for political and cultural representation of ethnic minorities in Western countries has resulted in greater visibility of hitherto marginalized groups, especially after the 1980s. One of these groups is the so-called "South Asian diaspora".

According to Stuart Hall, diasporic peoples have constructed their heterogeneous identities through a process of migration and dislocation that has compelled them to a continual production and reproduction of themselves through incessant transformation (1997: 58). On the other hand, Andrew Higson draws attention to the discourses of unity and fragmentation that characterize the construction of the diaspora, and he affirms that these communities are forged "in the tension between unity and disunity, between home and homelessness" (2006: 16). If hybridity is, therefore, a key term defining "diaspora identities", diasporic discourses might challenge "narratives of purity, rootedness, and timelessness" and, consequently, they are positioned "to dismantle nationalist constructions of belonging that link racialized and gendered bodies and space in seamless tales of bloodlines and family to the land" (Desai, 2004: 18).

The key issue here is the relevance of the concept of "identity" and how the close connection between culture and nationhood is put to the test by a borderless diasporic identity. In this sense, as Amartya Sen postulates, "identity is important as far as it provides a sense of belonging to a particular community". The negative counterpart of it is that "a sense of identity can firmly exclude many people as it warmly embraces others" (2007: 2). In turn, Chris Weedon highlights the fact that identity is plural, "fractured and reconfigured by gender, ethnic and class relations"; besides, she adds that constructions of identity are historically specific (2004: 20).

Both Sen and Weedon agree on the fact that identities are constructed relationally and that are culturally and historically contingent. This implies that, in spite of social constrictions, there is a certain freedom of choice to determine the extent to which one should cling to a particular identity. One should also take into consideration the degree of relevance that each identity may have in different social, geographical and historical contexts. However, not everybody is fully conscious of his/her freedom in this choice because this awareness 
implies certain instability. This instability is what characterizes global societies in "liquid modern times", to use Bauman's words. Societies are opened to new cultural influxes, which may result in enriching cultural interchange; however, this openness can be the source of fear of what is perceived as a threatening, uncertain otherness. Furthermore, in the case that one decides to choose and avoid social manipulation in issues of cultural identities, this freedom may be confronted with intolerance or lack of understanding, since: "our freedom to assert our personal identities can sometimes be extraordinarily limited in the eyes of others, no matter how we see ourselves" (Sen, 2007: 6).

This "limitation in the eyes of others" is what, more often than not, transnational cinema and, more concretely South Asian diasporic cinema, tries to challenge. The hybrid perspectives, offered by these productions, question - and even undermine- the fixed, narrow and exclusivist nature of cultural identities that certain social groups try to impose on others. Influenced not only by the successful Bollywood industry and the globalizing forces of Hollywood productions, but also by the indigenous cinemas of their host countries -i.e. Britain - the South Asian diaspora finds in the big screen a suitable place where to represent their conflicting identities located in temporal and spatial in-betweenness. As Jigna Desai puts it:

South Asian diasporic cinema is a developing cinema that negotiates the dominant discourses, politics and economies of multiple locations [...]. South Asian diasporic cinema negotiates and traffics among the two largest global cinemas -those of Hollywood and Bollywood- as well as individual national cinemas including British, Canadian, alternative U.S. and alternative Indian. Thus diasporic films function significantly as part of the shifting economic, political, and cultural relations between global capitalism and the post-colonial nation-state, raising questions regarding the negotiation of cultural politics of diasporas located within local, national and transnational processes (2004: 35-6).

In this sense, South Asian diasporic cinema can be analyzed within the general frame of transnationality, a term that Elizabeth Ezra and Terry Rowden define as: "the global forces that link people or institutions across nations [...]. The global circulation of money, commodities, information, and human beings is giving rise to films whose aesthetic and narrative dynamics, and even the modes of emotional identification they elicit, reflect the impact of advanced capitalism and new media technologies as components of an increasingly interconnected world-system" (2006: 2-4).

The concept of transnationalism is therefore related to that of diasporic cinema in that it trespasses the boundaries of the nation not only in terms of production, distribution and exhibition but also in terms of thematic and formal cultural representations of diverse identities in the narrative of the film. In their critical analysis of the concept of transnational cinema, Will Higbee and Song Hwee Lim point at the work of diasporic and postcolonial cinemas as one of the approaches to transnational cinematographic productions, which aims 
"to challenge the western (neo-colonial) construct of the nation and national culture and, by extension, national cinema as stable and Eurocentric in its ideological norms as well as its narrative and aesthetic formulations" (2010: 9). Higbee and Lim observe that this type of cinema explores the power relations at stake in binary oppositions such as centre/margin, insider/outsider, global/local, and host/home. (2010: 11).

According to this interpretation of transnational filmmaking, this type of film may therefore help formerly marginalized groups to gain a foothold in the ambit of cultural representation. Up until the 1990s, South Asian diaporic identities in the media were underrepresented or misrepresented, not only in their host countries but also in India. More concretely, in Britain, the hegemonic Thatcherite discourse of the 1980s championed a traditional white-homogeneous national identity. South Asian characters appeared mostly (mis)represented in the Raj productions which nostalgically harked back to imperial times of British dominance over India - e.g. David Lean's A Passage to India (1984), Richard Attenborough's Gandhi (1982) and the TV series The Jewel in the Crown (Morahan and O'Brien, 1984). Independent productions, though, were also produced in that decade, which explored the diversity of cultural identities in Britain under the "white mask" of hegemonic discourses, such as Stephen Frears' My Beautiful Launderette (1985) and Sammy and Rosie Get Laid (1987). On the other hand, in Bollywood productions, the South Asian diaspora was marginally represented, most of the time as negative examples or Westernization (Gangoli, 2005: 160; Kaur, 2005: 309; Lal \& Nandy, 2010: xviii).

In the 1990s, several people within South Asian communities had already managed to succeed both in economic and social terms; as a consequence, they had acquired certain power not only in their host countries but also in India, where their investments represented a significant contribution for the economic growth of the nation. It was against this background that South Asian diasporic filmmakers started to gain success and visibility. In Britain, Tony Blair's construction of "Cool Britannia" promoted a multicultural view of British identity; as a consequence, the 1990s and 2000s witnessed the production of several film and TV productions made by British-Asian filmmakers which explored the experience of South Asian diasporic communities in Britain. Some examples are Chadha's Bhaji on the Beach (1993) and Bend It Like Beckham (2002), East is East (O'Donnell, 1999), My Son the Fanatic (Prasad, 1997), Anita and Me (Hüseyin, 2002), Ae Fond Kiss (Loach, 2004), and the successful TV show Goodness Gracious Me (BBC, Carrivick et al. 1998, 2000, 2001). In India, the South Asian diaspora started to gain greater and more positive representation in mainstream productions, such as Dilwale Dulhania Le Jayenge (Chopra, 1995), Kabhi Khushi Kabhie Gham (Johar, 2001), and Swades: We, the People (Gowariker, 2004).

Jigna Desai declares that the South Asian community has experienced not only greater visibility, but even hypervisibility (2004: 69); he, nevertheless, highlights the post-9/11 schizophrenic representation of South Asian identity in the West: "This visibility is occurring simultaneously with the heightened racialization processes following the globalization of the 
events of 9/11. Hence, this visibility is accompanied by a bifurcation in which Asianness is hip, cool and British, and Asian themselves are dangerous and foreign" (2004: 68) ${ }^{5}$.

Accordingly, the 2000s have witnessed a revival in the confrontation between the inclusionary and exclusionary aspects of the processes of cultural identity and identification. Not only host countries may perceive people of South Asian descent as both "same" and "other", but PIOs (People of Indian Origin) and NRIs (Non-Resident Indians) also have to confront the different possibilities at stake under the label of "South Asian diasporic identities".

\section{BRIDE AND PREJUDICE: TRANSCENDING GENRES AND NATIONAL IDENTITIES}

Considering the contesting potential of transnational cinema, the analysis of a South Asian diasporic filmic adaptation of an English literary classic can be very telling. It could be said that Gurinder Chadha has created a new text through parody and pastiche, using Fredric Jameson's words (1992: xvii). Taking into account the ambivalent nature of parodic texts, Bride and Prejudice can be read, on the one hand, as homage paid to Austen's ironic representation of her own society that can easily be adapted to other times and places, and, on the other hand, as criticism of past prejudices in new contexts, by its combination or pastiche of different generic conventions. This criticism results mainly from the hybridization of three cinematic traditions - heritage cinema, Hollywood and Bollywood - which are closely associated with distinctive national cultures: British, U.S. American and Indian.

\subsection{Hollywood, Bollywood and Heritage Films}

Gurinder Chadha's version of Jane Austen's well-known novel not only breaks temporal boundaries but also geographical ones. Much has been already discussed on the fact that, in their transposition of past issues on contemporary screen fictions, historical or heritage films tell more about the present than they do about the past (Hill, 1999: 84). Thus, according to Rajeswari Sunder Rajan, "if we recuperate and reinstall Austen in our world, it is also an Austen for our times" (2005: 3). What is more, the endless direct and indirect references to Jane Austen in contemporary films -and novels- "allow us to prove the complicit relationship between patriarchy and capitalism in transitional societies" (Rajan 2005: 11). This has been the case of the other British and Hollywood adaptations of Pride and Prejudice, such as Robert Z. Leonard's 1940 Hollywood version, and the 1995 joint BBC/A\&E version (see Ellington, 2001, and Belton, 2003). Bridget Jones' Diary (Maguire, 2001) brought Austen's characters and story to contemporary Britain, but it was Bride and Prejudice that completely dislocated the story in spatial terms. 
In Bride and Prejudice, taken-for granted prejudices are nakedly exposed. Consequently, unquestioned historical connections and geographically located cultural identities, which have traditionally and exclusively been associated with certain social groups, can now be destabilized and deconstructed. In this sense, as a transnational movie, it manages to transcend the boundaries, not only of cinematic genres -in both form and content-, but also of national identities, and the link that is often established between these two categories. At this point it is important to mention Rick Altman's definition of cinematic genres as processes in constant evolution that result in new creations in contingent contexts. This occurs when marginal generic categories manage to become visible and associate themselves with central ones. Significantly enough, Altman draws attention to the fact that the same process takes place in the "genre" or identity of nations: nations are sites of continuous struggles between competing marginal and central discourses that may evolve dialectically towards new hybrid orders (1999: 199). Taking Altman's theory into account, Bride and Prejudice could also be interpreted as the site where the categories of genre and nation are contested in a process that aims to create a new hybrid outcome.

To begin with, Bride and Prejudice subverts the principles of the British heritage cinema by adapting - or, using Geoffrey Wagner's terminology, making an "analogy" of - a novel that epitomizes canonical English Literature from early nineteenth-century England to early twenty-first-century India. ${ }^{6}$ This temporal and spatial dislocation serves to question the cultural imposition of the UK over India, an imposition which finds its origins at the time of the Empire and that, at that time, went hand in hand with economic domination. According to Gayatri Spivak, the Indian student of English literature has suffered "a gradual cultural alienation", as s/he: "is called upon to relate to the culture of "a vague space called Britain, even England, in its transaction with Europeanness (meaning of course Western Europe), Hellenism and Hebraism, the advent of Euroamericanism, the trendiness of Commonwealth literature, and the like" (in Rajan 2005: 13).

By appropriating this particular novel by Jane Austen, Chadha puts to the test the prejudices that hierarchal structures of power generate. Among other things, Austen's Pride and Prejudice deals with the important role of economy in society, exemplified in the dichotomy marriage transactions vs. love relationships, together with the prejudices that individuals belonging to different social backgrounds may have against each other. Chadha's Bride and Prejudice hints at the pervasive force of such prejudices prevailing in our contemporary globalized societies, not only in terms of class but also of race and gender. By evoking Jane Austen's text, Chadha highlights the influence of history on contemporary cultural identities while, at the same time, she questions the very notion of "heritage" as exclusive inheritance of a particular group. In other words, Chadha, in her film, reflects the heterogeneity and continuous re-construction of diasporic communities. Jane Austen is a symbol of English letters, however, because of historical reasons, canonical English literature forms part of the cultural background of formerly colonized people as well. As said before, 
during the 1980s, there was a generalized and nostalgic harking back to the past in Britain with the appearance of museums, heritage centers, literary historiographic metafictions and heritage films. This phenomenon apparently went in line with the Thatcherite government discourses which defended a return to the values of the past that had been forged at a time when the term "British" was associated with "whiteness" and "Empire" (Higson, 2003; Hill, 1999; Rushdie, 1992; Woolen, 1991). Against this background, heritage films usually stood for this nostalgic return to the past in their portrayal of a "white", "upper-class" and "imperial" British heritage.

Taking into account that Bride and Prejudice is an adaptation of a well-known English literary classic, and that it follows some generic conventions that been consistently attributed to heritage productions, it could therefore be categorized as a "heritage film". These movies often present a "museum aesthetic" (Higson, 2003: 37-9, Monk 2002: 178). Accordingly, Chadha's production carefully portrays the lives and splendor of the upper classes, highlighting the details of the in-house decorations of the settings where the different dances and wedding ceremonies take place. In London, Balraj's wealthy house next to Windsor Castle ironically hints at heritage productions which foregrounded the properties of the upper-classes in both content and form of the film -such as Ivory's Howards End (1992). Likewise, the establishing shot of Darcy's luxurious hotel in Los Angeles replicates the impressive façade of Pemberley as shown in the 1995 BBC version of Pride and Prejudice. Similarly, the first dancing number makes reference to the ballroom scenes that appear in British heritage films adapting Austen novels. In spite of the different dancing styles Bollywood vs. classical English ballroom dance - the camera movements showing the couples dancing holding hands in a perfect choreography replicate those shootings of heritage productions such as Persuasion (Mitchell, 1995), Sense and Sensibility (Lee, 1995) and the BBC version of Pride and Prejudice (Langton, 1995) ${ }^{7}$.

It is also interesting to notice that some of the heritage films made in the 1980 s were set in India at the time of the British Empire. These so-called Raj productions turned spectators into tourists by showing them spectacular shots of the landscape, thus emphasizing the beauty of Britain's possessions. Some well-known examples of the so-called Raj productions are Attenborough's Gandhi (1982), Lean's A Passage to India and the TV series The Jewel in the Crown (Morahan and O'Brien, 1984). Following the generic conventions of the Raj films, Bride and Prejudice offers the same kind of visual pleasures for the audience, although at a global scale: In India, spectators can enjoy views of the Golden Temple in Amritsar, the seaside in Goa, as well as the splendorous indoor settings where the wedding takes place. London glows as seen from the London Eye, and Los Angeles, in turn, is shown as a modern and cosmopolitan place, with skyscrapers seen from a helicopter, luxurious hotels, and beautiful beaches.

If interpreted as a "heritage film" Bride and Prejudice problematizes this view of "heritage" as an exclusively national and ethnic phenomenon. Chadha's transnational version 
of Jane Austen's novel, which offers a constant dialogue between different cultures, opens up the exclusivist and narrow limits of the term "heritage" in relation to the construction of cultural identities. Bride and Prejudice, therefore, highlights the fact that Jane Austen's works not only form part of the British heritage, but they have also been inherited by people from other cultural backgrounds.

Apart from these references to British heritage productions, Bride and Prejudice also recalls the conventions that characterize Bollywood movies. Recurrent elements in Indian popular cinema are music, color, fantasy, melodramatic exaggeration of emotions and situations, escapism into the luxuries of the upper classes, as well as a romantic plot between the hero and heroine that finally unifies all the family. Musical numbers include Oriental rhythms and melodies, however, those sung in English also hint at Hollywood musicals. This reference to Hollywood is also patent in the romantic plot and happy ending, which follow the conventions of a U.S. American romantic comedy. The film mixes up these two cinematic ways of presenting a love story; however, it goes beyond these conventions by including an interracial romance. Societies that construct their national identities upon binary oppositions fear that miscegenation and hybridity may destabilize a social order based on this type of dual categories. That is why popular media in general and mainstream cinema in particular have pervasively avoided the portrayal of the heterosexual interracial romance with the exception of Romeo-and-Juliet-like unfulfilled -and childlesslove stories. The happy ending which unites the couple subverts the long-standing avoidance of portraying heterosexual interracial romances in positive terms in both Hollywood and Bollywood traditions.

In cinema, the encounter of Eastern and Western cultures has often been symbolized by metaphors of sexual attraction appearing in Hollywood and British films set at the time of the Empire. This figurative relationship is represented in three variants. The first involves a Western man and an Eastern woman, a type of relation which stands for the European, patriarchal colonial dominance over the feminized Orient. The second represents the East and the West in terms of male friendship, which points to the increasing equality between the two cultures - the counterpart is a homoeroticized encounter that brings to the fore homosexual intercourse developing into sadistic relationships of power. The third variant is a reversal of the first one, involving a Western woman and an Eastern man, which never results in a happy ending (Hill, 1999: 106-112). Bollywood films openly avoid this issue and if it occasionally appears, it portrays a male hero first attracted by a Western woman but who finally refuses her in favor of a traditional Indian match representing good, traditional, national values. This happens in movies such as Kisna, the Warrior Poet (Ghai, 2005) and in Lagaan, Once Upon a Time in India (Gowariker, 2001).

From both an Eastern and Western point of view, the power relationships at stake in the interracial romance are subverted in Bride and Prejudice: a Western man abandons his country and questions his culture to follow his Indian bride to her country and accepting her 
traditions. Before the final happy encounter of the couple, the heroine is tested by a "wrong partner", the British Wickham (Daniel Gillies). The relationship they have is quite significant, taking into account the analyses on cultural identities mentioned above: when Lalita falls in love with Wickham, she dreams about leaving her own family and culture to take up her lover's British identity. She imagines herself "dressed in white" in her wedding and living "the land of Her Majesty". What happened to be a dream is suddenly transformed into a nightmare when Darcy appears and tries to force her to an unwanted kiss. This scene represents the long-standing cinematic tradition of dominant male characters imposing their culture and values upon their exotic bride -as occurred in the first variant of the cinematic portrayal of the interracial romance in Hollywood and British Empire films. It will not be until Darcy opens up his mind and is ready to accept Lalita's cultural background that he becomes the right partner for her.

In contrast to the nightmare, the ending of the film portrays a hero who has finally overcome his cultural prejudices. He is dressed in Indian clothes, has learnt to play the Indian drums and is ready to have an Indian wedding - with a bride dressed in red. The ending, though, is open in the sense that the film never explains where the couple is going to live after their marriage. However, the setting of the wedding and the portrayal of a male hero imbued in the heroine's culture is quite significant as it departs from the traditional representations of the heterosexual interracial romance explained above.

Darcy is not the only prejudiced character at the beginning of the film. Actually, all characters hold prejudiced views against "other" groups. Prejudices not only arise from cultural confrontations between Eastern and Western cultural misunderstandings embodied by Darcy and Lalita; they are also present in the relationships between Indians living in India and those living abroad. Balraj's sister, Kiran (Indira Varma), stands for those Westernized Indians in the diaspora who live very comfortably in their host country and feel superior with respect to their compatriots in their mother land. Their wealth and upper-class status lead them to think that people in India only want to establish relationships with them because of their money.

Balraj (Naveen Andrews) -Mr. Bingley's Indian counterpart- does enjoy the particularities of British and Indian cultures; however, influenced by his sister's snobbish attitude and Darcy's concerns on Mrs. Bakshi's (Nadira Babbar) economic interests in marriage, Balraj breaks his relationship with Jaya (Namrata Shirodkar), fearing that those prejudices may be true. Balraj and Kiran seem to have internalized the British cultural image of the upper classes' stiff-upper-lip attitude in their refusal to relate themselves too closely to people belonging to lower strata of the social scale, especially with people from abroad. The film thus satirizes the behavior of those Indians from the diaspora who identify themselves with that traditional, chauvinist and supercilious and even racist British attitude -an attitude often portrayed in the Raj films mentioned above- which is shown against people from India. 


\subsection{Seeing from the Other's eyes}

Binary oppositions based on unequal power relations fuel the proliferation of prejudices. Such prejudices tend to simplify the Other's culture in order to be in control of it, often for economic purposes. The film not only offers the interracial romance to subvert Hollywood and Bollywood misrepresentations of miscegenation; the romance is also presented as a tool to overcome prejudices: love allows the characters to see a different culture from the eyes of the Other. This change in perspective shows that all cultures are inherently hybrid, thus containing a wide range of possibilities of identification.

This plurality of identities is reflected in the different musical numbers performed in the film which are associated with the symbolic meaning of each setting -Amritsar, Goa, London and Los Angeles. The first one is a typical Bollywood choreography in a wedding film which portrays the Indian upper classes and distinctive cultural traditions regarding marriage and wedding celebrations. The following dance depicts another side of India. It takes place in the street market where the three friends go shopping. This is the India associated with the common people and everyday life working activities. Apart from the different types of merchants, three eunuchs appear in the song to tell the bride's fortune. Although they have a very brief performance, their very presence in a film about brides and weddings disrupt the dominant patriarchal hetero-normativity of mainstream Indian films (Pendakur, 2003: 145-6). The last dance sequence in Amritsar is the Raas one, which symbolizes traditions and folklore present in contemporary Indian society and the way the main characters in the film manage to combine both tradition and modernity.

Amritsar is a relevant setting. This Punjabi city symbolizes the multiplicity of religious communities that co-habit in the Indian subcontinent. The Golden Temple is the centre of Sikhism, thus the film departs from Bollywood's usual focus on Mumbai and Hinduism ${ }^{9}$. The Temple is highlighted by an establishing shot at the beginning of the film, in a musical number, and by being mentioned by Lalita and Wickham. This city is also unfortunately known by the Amritsar Massacre, when in 1919, in the context of social unrest due to people's demands for India self-rule, British troops shot a peaceful gathering of people in an enclosed garden, causing 379 deaths and 1500 casualties (Mattazzi, 2002: 54-55). The Amritsar Massacre is portrayed in Attenborough's Gandhi (1982) and is shown to impel the Mahatma to his non-cooperation campaign. Consequently, the reference to Amritsar in Bride and Prejudice, a film with a strong emphasis on intercultural relationships in postcolonial times, could also be taken as an intertextual reference, a characteristic feature of Bollywood cinema.

In 1947 Amritsar also became a site of conflict between Hindus, Muslims and Sikhs after the partition of India divided the Punjabi territory between India and Pakistan. Accordingly, Amritsar stands for a place where violent confrontations took place in terms of identity domination - imperialism and religious fundamentalism - but it also symbolizes 
plurality and peaceful conviviality of cultures that can enrich people's identities if understood, tolerated and appreciated by their "otherness".

The next musical number takes place in Goa, where the African-American singer Ashanti performs a song that combines both Eastern and Western rhythms as contemporary Bollywood films do, and which says that "India can set you free ${ }^{10}$ ". This is a "Western" ingredient of a globalized India which is accepted as long as it does not engulf the indigenous cultural expressions. This number represents the film's celebration of cultural hybridity when economic imperialist relationships are left behind. The song precisely comes after Darcy is accused of neo-imperialism in his business transactions, that is, imposing his own standards upon the culture of a country he does not really care about, except for economic matters; in other words, he wants to make money without actually investing in that particular country.

After his argument with Lalita, he starts to reconsider his thoughts and beliefs. Lalita tells him that a luxurious hotel in Goa, similar to any other seaside resort in any other country, is not "real India". After that conversation, Lalita is shown playing cricket with Indian children on the beach ${ }^{11}$. The following sequences show Darcy contemplating these scenes and thus starting to look at the different aspects of India through Lalita's eyes. He becomes interested in India's indigenous culture and stops regarding the country simply as a place to do business and get benefits -that is, he reconsiders his neo-imperialist attitude in favor of a one-to-one relationship in terms of equality. The "real India" Lalita makes reference to, the India that "can set you free" is, in fact, many "Indias".

Significantly enough, Goa also appears as a symbolic place in the movie, as it represents the plurality of identities present in the subcontinent. It was a Portuguese and not a British colony, consequently, the historical cultural influences in this place vary with respect to the rest of the Indian subcontinent -a particularity of this place is the large Christian community it holds if compared to other regions of the country (a 30\% of the population), with its subsequent cultural particularities ${ }^{12}$.

It is important to notice that, in the film, Western -or Westernized- characters, however, are not the only ones that must overcome their prejudices. Lalita also experiences a transformation in his trip to Los Angeles -as Lizzy did in her visit to Pemberley in Austen's novel. After contemplating the city through Darcy's eyes, she becomes aware of the plurality of identities that cohabit in the United States, and that her view of all Americans as imperialists does not stand for "real America". It is true that Darcy's mother, Catherine (Marsha Mason), is portrayed as a chauvinist character that only cares for her own economic status and the values of her nation. Mrs. Darcy exhorts Lalita to tell her "everything about India", and adds that she would love to visit the country if one of her hotels were there; yet she remarks: "With yoga, spices, Deepak Chopra and all the wonderful Eastern things here, I suppose there is no point in travelling there any more". Her views are comically ridiculed in the film, especially by Lalita's reply, pointing that "just because there is a Pizza Hut around the corner people have not stopped going to Italy". Although Mrs. Darcy does represent a 
sector of U.S. American society, she does not stand for the whole of it, and this is the important lesson that the heroine learns in Darcy's place.

Lalita is first surprised when Darcy takes her to a Mexican restaurant for dinner, a sign of the multiculturality of the place, present at the very origins of the city of Los Angeles. The Mexican singers serve as the starting point of fantasy and romance in a typically Bollywoodean musical number -dance and music replace explicit sexuality, which has been usually censored in Bollywood productions. This song depicts Los Angeles as a multicultural city where Mexicans, a Gospel Choir composed mainly by African-American people, and even some white surfers participate in the choreography that stands for Darcy and Lalita's love. The helicopter the couple takes serves to show a great variety of landscapes -the city, the desert, the canyon, the sea- which symbolically stand for the equally diverse identities that co-habit in that area. There are several scenes in this musical sequence which portray Lalita looking at the places Darcy indicates. From the expression of her face, one can see that she enjoys the views, precisely because she is now contemplating the sites from Darcy's perspective - as he had previously done in India.

These scenes representing the main characters seeing new places from the eyes of the Other are reinforced by the lyrics of the song. Although it is basically a love song accompanying the romantic plot, "Take Me to Love" can also be interpreted as love itself helping overcome cultural prejudices: "Show me the way / Take me to love / Things only heard / now I want to feel/see/be". A female voice sings that she wants to experience love by herself, that is, she wants to feel, to see, to be all those things that she only knows by listening to other people's experiences. At the beginning of the film, we learn that all prejudices against the "Other's culture" both Lalita and Darcy have are the result of their partial knowledge they have of the other's country. Nevertheless, it is love that makes them gain more interest in avoiding prejudices and getting to know the complex realities of different countries and peoples. In consequence, "Show me the way / take me to love" may be interpreted as love showing an alternative way to look at the Other.

Even though no musical number takes place in London, the city is also portrayed through spectacular long shots in the film, and depicted as a site embracing a great variety of identities. Apart from the luxurious mansions of the British-Asian upper classes in the country-side, the association of Lalita's younger sister Lakhi's (Peeya Rai Choudhuri) with Wickham allows the spectator to see other different areas of the place, such as the canals of Camden Town, and the touristic sights one can see from the London Eye. Lakhi gets very excited when she realizes that movie theatres show Bollywood films, which highlights a significant presence of a South Asian community in Britain. Although Wickham turns out to be the wrong partner for both sisters, Lakhi's love for him makes her an enthusiast in getting to know the Other's culture. Thanks to her, the audience is allowed to visually enjoy the plural identities present in "real Britain" apart from the values of the English upper classes that have pervasively been associated with the British identity as a whole. 
As a conclusion, it could be said that Bride and Prejudice re-enacts Austen's plot of love and money in a contemporary, globalized world, where the capitalist drives that prioritize economic transactions oven human relations. This negative side of globalization may contribute to fuel social and cultural fears and prejudices that prevent multicultural tolerance and hinder the freedom to choose one's identity. Following Bollywood and Hollywood conventions of romantic comedies and musical romances, the film offers an escapist fantasy in which love triumphs and manages to do away with all kinds of prejudices. In the final wedding scene, all the characters are reconciled in the double and interracial wedding. The scene presenting Indian elephants with a "Just Married" sign comically provides the conclusion of love in a multicultural context in which identities are plural and any individual should be free to make his own choices and scale of priorities. As Amartya Sen states:

There is a compelling need in the contemporary world to ask questions not only about the economics and politics of globalization, but also about the values, ethics and sense of belonging that shape our conception of the global world. In a nonsolitarist understanding of human identity, involvement with such issues need not demand that our national allegiances and local loyalties be altogether replaced by a global sense of belonging, to be reflected in colossal "world state". In fact, global identity can begin to receive its due without eliminating our other loyalties (2007: 185).

Due to their delocalized nature, this combination of global and local identities is what a transnational film like this presents to contemporary audiences. The multicultural experiences of filmmakers from the South Asian diaspora offer new perspectives on identity issues which highlight the possibility of individuals to freely choose their own identities in a plural world.

\section{NOTES}

1. The research of this paper has been financed by the Ministerio de Educación, Ciencia y Tecnología through the research project FFI2010-15263.

2. The director, of Indian background was born in Kenya and grew up in the UK. The scriptwriter, Paul Mayeda Berges, her husband, is a Japanese-American, and the main production company is Pathé International, associated with other British and U.S. American companies (http://www.imdb.com/ title/tt0361411/companycredits; 15/02/2011). James Berardinelli describes the film as "one of the new breed of Hollywood/Bollywood offspring. It's an American/British co-production, and, while Disney money is involved, it is filtered through Miramax. The influence of both parents is apparent. Bride and Prejudice uses many top Indian actors, and the style is heavily influenced by the Bollywood approach (which is famous for sprinkling lavish musical numbers throughout an otherwise dramatic production). There's plenty of Hollywood here, as well. The film is in English and has a sizable budget" (http://www.reelviews.net/php_review_template. php?identifier=1122; 23/04/2011).

3. David Cornelius describes the film as the use of the worst parts of three different genres and argues that: "duplicating the Bollywood formula elsewhere is a recipe for disaster" (http://efilmcritic. com/review.php?movie=11131\&reviewer=392: 23/04/2011). Mark Pfeiffer also 
highlights the failure at mixing different styles: "The end result looks and feels like a cut-rate version of the Bollywood and Hollywood sensibilities" (http://reeltimes.blogspot.com/2005/03/bride-prejudice.html, 22/04/2011).

4. In contrast to David Cornelius view, James Berardinelli comments on the genre mixture offering a positive outcome: "This particular match, arranged by Gurinder Chadha, finds a surprisingly rich field of common ground. Bride and Prejudice is bright, colorful, and exhilarating, and brings new dimensions to a story that has been told so many times that it's astounding to recognize that someone has found a fresh perspective". (http://www.reelviews.net/php_review_template.php?identifier=1122; 23/04/2011). Similarly, Priyanka Gill explains that "Chadha's forte lies in portraying a British-Asian sensibility" (http://www.tehelka. com/story_main4.asp?filename=hub073104Jane_Austen.asp; 23/04/2011). Criticizing those negative reviews of the film by Jane Austen "purists", Peter Travers gives a similar positive view of the film's hybridity. (http://www.rollingstone.com/movies/ reviews/brideand-prejudice-20050127; 23/04/2011).

5. This double vision of people of South Asian origin as 'same' and 'other' is clearly exemplified in Peter Kominsky TV series Britz (2007).

6. Geoffrey Wagner's "analogy" means the use of a original text as a point of departure for the making of a new film (in Cartmell and Whelehan, 1999: 24).

7. I want to thank Dr Clara Calvo for her insightful comments on this issue during a seminar in 2007 at the University of Zaragoza.

8. This could be interpreted as a symbol of Lalita's Westernization, since Hindu brides dress in red as occurs at the end of the film, when she marries Darcy - and white, in India is the color for funerals and widows.

9. See Encyclopædia Britannica, Encyclopædia Britannica Online. 2010, viewed 2 March 2010 http://www.britannica.com/EBchecked/topic/21837/Amritsar 02/03/2010

'Religions: Sikhism', BBC, viewed 2010. http://www.bbc.co.uk/religion/religions/sikhism/ataglance/glance.shtml\#findoutmore

10. Ashanti is an African-American singer, whose name proudly makes reference to an ancient African tribe. Her presence in the film could be interpreted as yet another element of multiculturality in a globalized world.

11. This scene could also intertextually hint at Lagaan (Gowariker, 2001), a film which uses cricket as a metaphor for colonial domination and which won the Oscar for best foreign film in 2002.

12. See 'Religions in Goa', Maps of India, viewed 2 March 2010.

http://www.mapsofindia.com/maps/goa/people-culture-and-festivals/religions-in-goa.html

\section{REFERENCES}

Altman, R. (1999). Film/Genre. London: British Film Institute.

Berardinelli, J. (2010) Bride and Prejudice. A movie review by James Berardinelli. In Reelviews. http://www.reelviews.net/php_review_template.php?identifier=1122. Viewed 23 April, 2011.

Belton, E. (2003). Reimagining Jane Austen: the 1940 and 1995 film versions of Pride and Prejudice. Gina Macdonald \& Andrew Macdonald (Eds.), Jane Austen on Screen (pp. 175-196). Cambridge: Cambridge University Press.

Bauman, Z.(2007). Liquid Fear. Cambridge and Malden: Polity Press.

Bride and Prejudice. Retrieved from

http://www.planetbollywood.com/displayReview.php?id=032906112631. Viewed 22 April, 2011.

Cartmell, D. \& Whelehan, I. (1999). Adaptations: From Text To Screen, Screen To Text. London and New York: Routledge.

Desai, J. (2000). Beyond Bollywood. The Cultural Politics of South Asian Diasporic Film. London and New York: Routledge.

Ellington, H. (2001). A Correct Taste in Landscape. In L. Troost and S. Greenfield (Eds). Jane Austen in Hollywood (pp. 90-110). Kentucky: University Press of Kentucky. 
Encyclopadia Britannica, Encyclopadia Britannica Online. Retrieved from http://www.britannica.com/EBchecked/topic/21837/Amritsar. Viewed 2 March 2010

Ezra, E. and Rowden, T. (2006). Transnational Cinema: the Film Reader. London: Routledge.

Gangoli, G. (2005). Sexuality, Sensuality and Belonging: Representations of the 'Anglo-Indian' and the 'Western' Woman in Hindi Cinema. In K. Raminder \& A. Sinha (Eds.), Bollyworld. Popular Indian Cinema through a Transnational Lens (pp.143-162). New Delhi, Thousand Oaks, London: Sage.

Gill, P. Jane Austen, Indian Style. Tehelka, 31 July, 2001. Retrieved from http://www.tehelka.com/story_main4.asp?filename=hub073104Jane_Austen.asp. Viewed 23 April, 2011.

Hall, S. (1997, 1996). Who Needs Identity? In Stuart Hall and Paul du Gay (Eds). Questions of Cultural Identity (pp. 1-18). London: Sage.

Higbee, W. and Hwee, L. (2010). Concepts of Transnational Cinema: towards. A Critical Transnationalism in Film Studies. Transnational Cinemas. 1:1, 7-21, doi: 10.1386/trac.1.1.7/1

Higson, A. (2003). English Heritage, English Cinema. Costume Drama Since 1980. Oxford: O.U.P.

Higson, A. (2006). The Limiting Imagination of National Cinema. In E. Ezra \& T. Rowden (Eds.), Transnational Cinema: the Film Reader (pp.15-26). London: Routledge.

Hill, J. (1999). British Cinema in the 1980s. Oxford: O.U.P.

Jameson, F. (1992). Postmodernism and the Cultural Logic of Late Capitalism. London: Verso.

Kaur, R. (2005). Cruising on the Vilayeti Bandwagon: Diasporic Representations and Reception of Popular Indian Movies. In K. Raminder and A. Sinha (Eds.). Bollyworld. Popular Indian Cinema through a Transnational Lens (pp. 309-329). New Delhi, Thousand Oaks, London: Sage.

Lal, V. \& Nandy, A. (2010, 2006). Introduction: Popular Cinema and the Culture of Indian Politics. In Lal, V. \& Ashis N. (Eds.), Fingerprinting Popular Culture (pp. viii - ix). Oxford: Oxford University Press

Monk, C. (2002). The British Heritage-Film Debate Revisited. In C. Monk \& A. Sargeant (Eds.), British Historical Cinema (pp. 177-198). London: Routledge.

Pendakur, M. (2003). Indian Popular Cinema. Industry, Ideology and Consciousness. Cresskill, New Jersey: Hampton Press, Inc.

Pfeiffer, M. (2005). Bride and Prejudice. In Reel Times: Reflections on Cinema, 25 March, 2005. Retrieved from http://reeltimes.blogspot.com/2005/03/bride-prejudice.html. Viewed 22 April, 2011

Rajan, R. (2005). Austen in the World: Postcolonial Mappings". You-Me Park and Rajeswari Sunder Rajan. The Postcolonial Jane Austen (pp. 3-26). London and New York: Routledge.

Religions in Goa. In Maps of India. Retrieved from http://www.mapsofindia.com/maps/goa/peopleculture-and-festivals/religions-in-goa.html. (Viewed 2 March 2010).

Religions: Sikhism. In $\quad$ BBC. http://www.bbc.co.uk/religion/religions/sikhism/ataglance/glance.shtml\#findoutmore. (Viewed 2 March 2010).

Robertson, R. (1994, 1992) Globalization. Social Theory and Global Culture. Sage: London, Thousand Oaks, New Delhi.

Robertson, R. (1995). Glocalization: Time-Space and Homogeneity-Heterogeneity. In M. Featherstone, S. Lash \& R. Robertson (Eds.), Global Modernities (pp. 25-44). London: Sage.

Rutherford, J. (1997). Forever England. Reflections on Masculinity and Empire. London: Lawrence and Wishart.

Sen, A. (2007, 2006). Identity and Violence. The Illusion of Destiny. London: Penguin.

Steger, M. (2003).Globalization: A Very Short Introduction. Oxford: O.U.P.

Travers, P. (2005). Bride and Prejudice. In Rolling Stone, 27, January, 2005. Retrieved from http://www.rollingstone.com/movies/reviews/bride-and-prejudice-20050127 (23 April 2011).

Weedon, C. (2004). Identity and Culture. Narratives of Difference and Belonging. Maidenhead: Open University Press.

Wollen, T. (1991). Over our Shoulders: Nostalgic Screen Fictions for the 1980s. In J. Corner \& S. Harvey (Eds.), Enterprise and Heritage: Crosscurrents of National Culture (pp. 178-193). London: Routledge. 